\title{
Effect of Industrial Effluents on the Germination and Seedling Growth of Three Leafy Vegetables
}

\author{
Shameem Ara Begum, M. Jahangir Alam, Syed Shayfur Rahman and M. Mizanur Rahman* \\ Department of Chemistry, Shahjalal University of Science \& Technology, Sylhet 3114, Bangladesh
}

\begin{abstract}
This study was conducted to determine the effect of industrial effluents on seed germination and seedling growth of some leafy vegetables under pot culture condition. Waste water sample was collected from natural gas fertilizer factory Limited, Fenchuganj, Sylhet. Four different leafy vegetables were selected as test crop to grow using these effluents. The design of the experiment was randomized complete block. The effects of different concentration of effluent were compared to that of distilled water (control). The results revealed that different concentrations of the extract caused significant inhibitory effect on germination and root elongation but benefited the shoot elongation. Maximum reduction in germination and root length was observed with the increase in effluent concentration, but increasing the shoot length. Bioassays indicated that the effects were proportional to the concentrations of the effluents and higher concentration showed stronger effect. Different physicochemical parameters of water e.g. pH, temperature, conductivity, dissolved oxygen (DO), chemical oxygen demand (COD), turbidity, Total dissolve solids (TSS), total suspended solids (TSS) etc. of the sample was also analyzed. It was found that the values were far apart from the optimum values that require for safe aquatic environment to establish an aquatic ecosystem on water body. It can be concluded that polluted water is becoming a threat for the crops and also for aquatic environment with the passage of time as more and more wastes are becoming a part of it.
\end{abstract}

Key words: Industrial effluents, Aquatic environment, Seed germination, Seedling growth, Pollution.

\section{Introduction}

Environmental pollution is a matter of great concern and has been accepted as a global problem because of its adverse effects on human health, plants, animals, and exposed materials (Irshad et al, 1997). Usually the industries, through their effluents pollute different water bodies e.g. river, canal sea etc. Pollutants may be toxic organic and inorganic or dissolve and suspended solids (Moeller et al, 1992). Water pollution is a result of addition of large amount of toxic materials (Terry, 1996). The major causes of water pollution can be classified as municipal, agricultural and industrial wastes. Industrial wastewater usually contains specific and readily identifiable chemical compounds (Benard et al, 1998). The effluents generated by various processes in industries are directly discharged without any treatment into the nearby water body. This results in increase or decrease of water $\mathrm{pH}$ and an increase of temperature, biological oxygen demand (BOD), chemical oxygen demand (COD), heavy metals and toxic chemicals (Santiniketan, et al, 1994). Effluents released with high temperature can raise the temperature of the water body, thus reducing the solubility of oxygen in the water. It also increases the $\mathrm{pH}$ value of the receiving body. The colloidal particle in the wastewater will increase the turbidity (Antonelli et al, 1999). Most of the industries of Bangladesh dispose wastewater without any treatment. Objective of this research was to determine the effect of industrial effluents on seed germination, for which wastewater sample was collected from Natural Gas Fertilizer Factory Limited, Fenchuganj, Sylhet. The germination of red amaranth (Amaranthus tricolor), amaranth stem (Amaranthus gangeticus), mustard (Brassica campestris), radish (Raphanus sativus) seeds were imposed under the influence of industrial effluents.

\section{Materials and Method}

The present study was conducted with five different concentrations (treatments) of wastewater collected from natural gas fertilizer factory limited, Sylhet. The treatments were made by dissolving calculated amount of waste water in distilled water i.e. control, 25, 50, 75 and 100\%. The following treatments were used in the experiments: $\mathrm{T}_{0}=$ seeds of

\footnotetext{
* Corresponding author: E-mail: mizan_sust@yahoo.com
} 
receptor plants grown in distilled water only (control), $\mathrm{T}_{1}=$ seeds of receptor plants grown in fruits extracts of $25 \%$ concentration, $\mathrm{T}_{2}=$ seeds of receptor plants grown in fruits extracts of $50 \%$ concentration, $\mathrm{T}_{3}=$ seeds of receptor plants grown in fruits extracts of $75 \%$ concentration, $\mathrm{T}_{4}=$ seeds of receptor plants grown in fruits extracts of $100 \%$ concentration.

The germination test was carried out in sterile petridishes having $12 \mathrm{~cm}$ in size placing whatman no. 40 filter paper on it. Each concentration of effluent was added to each petridish of respective treatment daily in such an amount just to allow the seeds to get favorable moisture for germination and growth. The control was treated with distilled water only. 20 seeds of each type of seed were placed in the petridish at room temperature $(26 \pm 2)^{\circ} \mathrm{C}$. The experiment extended over a period of 7 days to allow the last seed germination and measurement of the root and shoot length. The results were determined by counting the number of germinated seeds and measuring the length of primary root and main shoot on the 7th day of the experiment.

The ratio of germination and elongation were calculated as suggested by (Haque et al, 1971).

Relative germination ratio $(\mathrm{RGR})=$ (mean germination of tested plant $\div$ germination rate of control) $\times 100$.

Relative elongation ratio $(\mathrm{RER})$ of shoot $=$ (mean shoot length of tested plant $\div$ mean shoot length of control $) \times 100$. Relative elongation ratio $(\mathrm{RER})$ of root $=($ mean root length of tested plant $\div$ mean root length of control $) \times 100$.

Effluent taken from industry was subjected to different tests for analysis. Standard methods (Bazai et al, 2006) were used to determine $\mathrm{pH}$, conductivity, and total solids, dissolved solids, suspended solids, DO (Dissolve oxygen), BOD (Biological oxygen demand), COD (Chemical oxygen demand). The data were analyzed statistically and the difference between means were compared by LSD followed by DMRT (Duncun, 1957).

\section{Results and Discussion}

The out come of the analysis of physiochemical parameter is shown in the Table I. We found that the values were far apart from the optimum values that require in safe aquatic environment to establish an aquatic ecosystem on water body.

Due to degradation in water quality, it became a concern when population growth and industrial development produces a concentration of society's wastes that imperiled public health. Industrial effluents of fertilizer industry contain fertilizer as a waste, which may cause for the increasing shoot length. In addition, fertilizer industry effluent contains many anionic species, which can be beneficial for plant growth but its excessive level could be toxic, retard the growth of the plants. Fertilizer industry effluent may also contain ammonia that might play a role in enhancement of plant growth. Industrial effluents, present in waste water from manufacturing or chemical processes contribute to water pollution, which significantly affect the entire food chain (Howard et al, 1985). For the agriculture sector $\mathrm{pH}$ value take an important role in plant growth. The standard $\mathrm{pH}$ value needed for agriculture is 7-8. If the $\mathrm{pH}$ value is higher than standard value then it affects the plant growth. The $\mathrm{pH}$ value of industrial effluent was 8.67, this may be the reason for decreasing root length (Nawaz S., 2006). The temperature of industrial effluent is greater than room temperature. The high temperature reduces the solubility of oxygen in the water.

Table I. Physiochemical parameters of water containing industrial effluent collected from natural gas fertilizer factory limited, Fenchugang

\begin{tabular}{|c|c|c|c|}
\hline Parameters & Result & \multicolumn{2}{|c|}{ Optimum values ** } \\
\hline & & USPH Standard * & WHO * \\
\hline Temperature $\left({ }^{\circ} \mathrm{C}\right)$ Color, & 28 & & \\
\hline Odor, Taste & & \multicolumn{2}{|c|}{ Colorless, Odorless, tasteless } \\
\hline$\overline{\mathrm{pH}}$ & 8.67 & $6.0-8.5$ & $6.5-9.2$ \\
\hline DO & $0.93(\mathrm{~g} / \mathrm{L})$ & $4.0-6.0 \mathrm{ppm}$ & 4.0-6.0 ppm \\
\hline BOD & $0.5(\mathrm{~g} / \mathrm{L})$ & 5 ppm & $6 \mathrm{ppm}$ \\
\hline COD & 41.33(g/L) & $4.0 \mathrm{ppm}$ & $10 \mathrm{ppm}$ \\
\hline Conductivity ( $\mu \mathrm{s} / \mathrm{cm})$ & 616 & 300 & 300 \\
\hline Total dissolve solid & 11(g/L) & 500 ppm & 500 ppm \\
\hline Total solid & 146(g/L) & & \\
\hline Suspended solids (gm/L) & 135(g/L) & $5.0 \mathrm{ppm}$ & $5.0 \mathrm{ppm}$ \\
\hline
\end{tabular}

* USPH: United States Public Health. WHO: World Health Organization

**(source: Agarwal et al, 1996) 
As a result, fish and plant in the water can be affected (Ramamoorthy, et al, 1992).

The data presented in Table II revealed the effect of industrial effluent on seed germination. The germination of mustard (Brassica campestris) was stimulated by varying doses of applied effluent. Maximum germination was noted in T4 (100\%) and a minimum in $\mathrm{T}_{0}$ (control). correlated with the findings obtained by Bazai et al (2006), (Nawaz et al, 2006)

Table III represents relative shoot elongation ratio of the germinated seeds. The relative shoot elongation ratio of the germinated seeds increased with increasing concentration effluent. Highest stimulation observed in the case of radish $(R$. sativus) at $\mathrm{T}_{4}$ treatment $(+51.60 \%)$. Lowest stimulation

Table II. Effect of industrial effluent on the germination of some leafy vegetables grown in pot condition

\begin{tabular}{l|c|c|c|c|c|c|c|c}
\hline \multirow{2}{*}{ Treatment } & \multicolumn{7}{c}{ Receptor Plant } \\
\cline { 2 - 9 } & \multicolumn{2}{|c|}{$\begin{array}{c}\text { Mustard } \\
\text { B. campestris }\end{array}$} & \multicolumn{2}{c|}{$\begin{array}{c}\text { Amaranth stem } \\
\text { A. gangeticus }\end{array}$} & \multicolumn{2}{c}{$\begin{array}{c}\text { Radish } \\
\text { R. sativus }\end{array}$} & \multicolumn{2}{c}{$\begin{array}{c}\text { Red amaranth } \\
\text { A. tricolor }\end{array}$} \\
\cline { 2 - 9 } & RGR & PIE & RGR & PIE & RGR & PIE & RGR & PIE \\
\hline $\mathrm{T}_{0}$ & 65 & 0.00 & 100 & 0.00 & 85 & 0.00 & 100 & 0.00 \\
$\mathrm{~T}_{1}$ & 75 & $+15.38 \mathrm{a}$ & 75 & $-25.00 \mathrm{a}$ & 85 & $+0.00 \mathrm{a}$ & 90 & $-5.26 \mathrm{a}$ \\
$\mathrm{T}_{2}$ & 80 & $+23.08 \mathrm{~b}$ & 80 & $-20.00 \mathrm{~b}$ & 95 & $+11.76 \mathrm{~b}$ & 85 & $-10.53 \mathrm{~b}$ \\
$\mathrm{~T}_{3}$ & 80 & $+23.08 \mathrm{~b}$ & 75 & $-25.00 \mathrm{c}$ & 85 & $+0.00 \mathrm{a}$ & 80 & $-15.79 \mathrm{c}$ \\
$\mathrm{T}_{4}$ & 95 & $+46.15 \mathrm{c}$ & 70 & -30.00 & 80 & $+-5.88 \mathrm{~b}$ & 80 & $-15.79 \mathrm{c}$ \\
Mean & - & 26.92 & - & 25.00 & - & 13.23 & - & 11.84 \\
\hline LSD (5\%) & \multicolumn{7}{|c|}{3.99} \\
\hline
\end{tabular}

Within column, values followed by same letter(s) did not differ significantly at 5\% level by DMRT. Here, RER = Relative elongation ratio, PIE= Percent of inhibitory effect (-ve sign indicates inhibitory effect and +ve sign means stimulation)

The germination rate of mustard (Brassica camestris) increases with increasing concentration of effluent. The Relative germination rates of the amaranth stem (Amaranthus gangeticus) were noted maximum in $\mathrm{T}_{0}$ (100\%) and minimum in $\mathrm{T}_{4}(70 \%)$. That means the germination rate is almost inhibited with increasing concentration. Similar data were also observed in the case of red amaranth (Amaranthus tricolor). The Relative germination rate of was noted maximum in $\mathrm{T}_{0}(100 \%)$ and minimum in $\mathrm{T}_{4}(80 \%)$. That means the germination rate is decreasing with increasing the concentration of industrial effluent. These results are was observed in the case of mustard (Brassica campestris). Nevertheless, for the red amaranth (Amaranthus tricolor), the average shoot length is almost same for all concentration but greater than the average shoot length of $\mathrm{T}_{0}$ (control). Similar results were also reported by (Ramamoorthy et al, 1992).

Table IV represents average root length $(\mathrm{cm})$ of the germinated seeds. The average root length of mustard (Brassica campestris), amaranth stem (Amaranthus gangeticus) and radish (Raphanus sativus) are decreased with increasing concentration. Maximum inhibition was observed in the

Table III. Effect on shoot elongation ratio of the germinated seeds

\begin{tabular}{|c|c|c|c|c|c|c|c|c|}
\hline \multirow[t]{3}{*}{ Treatment } & \multicolumn{8}{|c|}{ Receptor Plant } \\
\hline & \multicolumn{2}{|c|}{$\begin{array}{c}\text { Mustard } \\
\text { B. campestris }\end{array}$} & \multicolumn{2}{|c|}{$\begin{array}{l}\text { Amaranth stem } \\
\text { A. gangeticus }\end{array}$} & \multicolumn{2}{|c|}{$\begin{array}{c}\text { Radish } \\
\text { R. sativus }\end{array}$} & \multicolumn{2}{|c|}{$\begin{array}{c}\text { Red amaranth } \\
\text { A. tricolor }\end{array}$} \\
\hline & RGR & PIE & RGR & PIE & RGR & PIE & RGR & PIE \\
\hline$\overline{\mathrm{T}_{1}}$ & 105.34 & $+5.34 \mathrm{a}$ & 123.23 & $+23.23 a$ & 130.32 & $+30.32 \mathrm{a}$ & 110.24 & $+10.24 \mathrm{a}$ \\
\hline $\mathrm{T}_{2}$ & 105.43 & $+11.07 \mathrm{~b}$ & 105.33 & $+29.80 \mathrm{~b}$ & 139.01 & $+39.01 b$ & 116.27 & $+16.27 b$ \\
\hline $\mathrm{T}_{3}$ & 108.25 & $+20.23 c$ & 107.00 & $+38.89 \mathrm{c}$ & 144.86 & $+44.86 b$ & 116.27 & $+16.27 b$ \\
\hline $\mathrm{T}_{4}$ & 103.65 & $+24.62 c$ & 101.82 & $+41.41 \mathrm{c}$ & 151.60 & $+51.60 \mathrm{c}$ & 118.67 & $+18.67 b$ \\
\hline \multirow{2}{*}{\multicolumn{2}{|c|}{$\frac{\text { Mean }}{\text { LSD (5\%) }}$}} & 5.67 & - & 9.34 & - & 41.45 & - & 15.36 \\
\hline & & 4.07 & & & & & & \\
\hline
\end{tabular}

Within column, values followed by same letter(s) did not differ significantly at 5\% level by DMRT. Here, RER = Relative elongation ratio. PIE= Percent of inhibitory effect. (-ve sign indicates inhibitory effect and +ve sign means stimulation). 
Table IV. Effect on root elongation of the germinated seeds

\begin{tabular}{|c|c|c|c|c|c|c|c|c|}
\hline \multirow[t]{3}{*}{ Treatment } & \multicolumn{8}{|c|}{ Receptor Plant } \\
\hline & \multicolumn{2}{|c|}{ Mustard B. campestris } & \multicolumn{2}{|c|}{ Amaranth stem A. gangeticus } & \multicolumn{2}{|c|}{ Radish $R$. sativus } & \multicolumn{2}{|c|}{ Red amaranth A. tricolor } \\
\hline & RER & PIE & RGR & PIE & RGR & PIE & RGR & PIE \\
\hline$\overline{\mathrm{T}_{1}}$ & 87.88 & $-12.12 a$ & 72.92 & $-27.08 a$ & 95.93 & $-4.07 a$ & 80.41 & $-19.59 a$ \\
\hline $\mathrm{T}_{2}$ & 66.88 & $-33.12 b$ & 58.98 & $-41.02 b$ & 94.70 & $-5.30 \mathrm{a}$ & 80.41 & $-19.59 a$ \\
\hline $\mathrm{T}_{3}$ & 61.65 & $-38.35 c$ & 55.50 & $-44.50 b$ & 82.48 & $-17.52 b$ & 86.15 & $-13.85 b$ \\
\hline $\mathrm{T}_{4}$ & 44.51 & $-55.49 d$ & 48.26 & $-51.74 c$ & 81.47 & $-18.53 b$ & 90.54 & $-9.46 b$ \\
\hline Mean & - & 34.77 & - & 41.08 & - & 11.36 & - & 15.62 \\
\hline LSD (5\%) & & 5.70 & & & & & & \\
\hline
\end{tabular}

Within column, values followed by same letter(s) did not differ significantly at 5\% level by DMRT. Here, RER = Relative elongation ratio. PIE= Percent of inhibitory effect. (-ve sign indicates inhibitory effect and +ve sign means stimulation).

case of mustard (Brassica campestris) at $\mathrm{T}_{4}(-55.49 \%)$. Minimum inhibitory effect was observed in the case of radish (Raphanus sativus) at $\mathrm{T}_{1}(-4.07 \%)$. These results are in accordance with the results obtained by Rao et al.(1983).

\section{Acknowledgement}

The authors are grateful to the Dept. of Chemistry, Shahjalal University of Sci. \& Tech., Sylhet, Bangladesh for giving necessary facilities during the research work.

\section{References}

Antonelli M. and M. Areeari (1999) Membrane treatment of secondary textile effluents for direct reuse. In: Advanced water treatment, Recycling and Reuse, pp: 409-416.

Anonymous Agarwal S. K., T. Swarnlata and P. S. Dubey (1996) Sources of Water Pollution In: Biodiversity and Environment. APH. Publishing Corporation, New Delhi, pp: 180-182.

Anonymous 1971. International Standards for Drinking Water 3rd Edn. WHO, Geneva.

Bazai Z. A. and Khan A. A. K. (2006) Effect of wastewater from Quetta City on the germination and seedling growth of Lettuce (Lactuca sativa L.). J. Appl. Sci. 6(2): 3800 - 382.

Benard J. and T. W. Wright (1998) In: Environmental Science (The Way the World Work) 6th Edn., Prentice Mall, New Jersey.

Duncun D.B. (1957) A significance test for differences between ranked treatments in analysis of variance. Virgina J. Sci. 2: 171-189.

Howard S. Peavy, Donald R. Rowe, George Tchobanoglous, (1985) Environmental Engineering, McGraw-Hill book company, Edn., pp: 22-23.
Irshad A., S. Ali and M. R. Jan, (1997) Physicochemical studies of industrial pollutants. Proc.

NSMTCC 97 on Environ. Poll. Islamabad, Pakistan February 24-26.

Moeller and W. Dade, (1992) Toxic Chemicals In: Environmental Health. USA. pp: 2.

Hoque, A. T. M. R., A.Romel, M. B. Uddin and M. K. M. Hossain (2003) Allelopathic effects of different concentration of water extracts of Eupatorium odoratium leaf on germination and growth behaviors were tested by using some agricultural crops. J. Biol. Sci. 3 (8): 741-750.

Nawaz S., Ali S. M. and Yasmin A. (2006) Effect of Industrial effluents on seed germination and early growth of Cicer arientum. J. Biological. Sci., 6(1): 4954.

Rao G. M. and N. V. Kumar (1983) Impact of tannery effluents on seed germination in Cicer arientum. Poll. Res. J., 2: 33.

Ramamoorthy K. D., Kalavathi and M. Paramasivam (1992) Maintenance of vigour and availability of stored pea seeds. J. Agron. Crop Sci., 169: 223-228.

Santiniketan M. R. and Visva-Bharati (1994) Industrial pollution of irrigation water. In: Affordable Water Supply and Sanitation, pp: 432-435.

Standard Methods for the Examination of water and wastewater, 5th edition, American public health association, Washington, D.C. 1981.

Terry L. A. (1996) Water pollution. Environ. Law. Prac., 4: 19-29.

Received : February 11, 2009;

Accepted : September 15, 2009 